\title{
Dentystyka w obozach koncentracyjnych na przykładzie KL Auschwitz i KL Stutthof
}

Słowa kluczowe: Stutthof, Auschwitz, gabinet dentystyczny, opieka medyczna, operacje szczęki, usuwanie zębów, złoto

Szczegółowe zagadnienie, jakim jest dentystyka w obozach koncentracyjnych, nie było dotychczas przedmiotem szerszych badań historyków zajmujących się funkcjonowaniem szpitalnictwa obozowego. Opracowania związane z tą problematyką są dość ogólne i skupione na konkretnej tematyce. Prócz niezwykle cennej oryginalnej niemieckiej dokumentacji temat dentystyki był poruszany we wspomnieniach przede wszystkim lekarzy-więźniów bądź ofiar, które miały styczność zarówno z samym gabinetem, jak i lekarzem odpowiedzialnym za leczenie uzębienia.

Jednym z pierwszych źródeł wprowadzających do tematu jest praca doktorska dentysty Wiktora Scholza $O$ możliwości ponownego stosowania złota $z$ jam ustnych zmartych, obroniona w Instytucie Stomatologicznym Uniwersytetu Wrocławskiego w 1940 r. Praca została wydana drukiem w Strzelinie ${ }^{1}$. Zagadnienie szybko doczekało się rozwiązania praktycznego, ponieważ już 23 września 1940 r. Reichsführer SS Heinrich Himmler wydał rozkaz usuwania złota dentystycznego ze zwłok więźniów, którzy zmarli w obozach koncentracyjnych².

${ }^{1}$ W. Scholz, Uber die Möglichkeit der Wiederverwendung des Goldes in Munde der Toten. Inaugural Dissertation zur Erlangung des Grades eines Dr der Zahnheilkunden der Hohen medizinischen Fakultät der Schlesischen Friedrich-Wilhelm Universität zu Breslau, Strehlen 1940.

2 Archiwum Państwowego Muzeum Auschwitz-Birkenau (APMA-B), Zbiór rozporzązeń SS-WVHA, t. 3, k. 227. 
Zobowiązał także zarządy obozów do dostarczania złota do centralnej administracji SS raz w miesiącu. Następnie Urząd Sanitarny (SS-Sanitätsamt) przydzielał otrzymane złoto gabinetom dentystycznym, z których korzystali członkowie załogi SS i ich rodziny. Od drugiej połowy 1942 r. ilość zdobytego złota była tak ogromna, że postanowiono umieszczać je w Banku Rzeszy. Dla przykładu warto zobrazować sytuację kilkoma danymi: na końcu marca i kwietnia 1944 r. dostarczono do SS-WVHA z Buchenwaldu 1191,545 g, z Neuengamme 142,17 g, z Sachsenhausen ponad $2030 \mathrm{~g}$ metali dentystycznych, z Oświęcimia 12 g złota określonego jako złoto dentystyczne, a oprócz tego 1673,8 g złota i 4367,1 g srebra, które mogło pochodzić z jamy ustnej pomordowanych więźniów3.

Najcenniejszym źródłem mówiącym o funkcjonowaniu dentystyki w obozach koncentracyjnych są wspomnienia więźniów, zarówno w postaci orzeczeń, opublikowanych monografii, jak i relacji na łamach „Przeglądu Lekarskiego - Oświęcim”. Na podstawie licznych zeznań więźniarek żydowskich z KL Stutthof oraz więźniów z Sonderkommanda $\mathrm{a}^{4} \mathrm{~W}$ KL Auschwitz wiadomo, że dentyści prowadzili ewidencję osób posiadających uzębienie wykonane z metali szlachetnych. O ile zęba nie usunięto przy rejestracji obozowej, wówczas wykonywano taki zabieg po śmierci ofiary, a ząb przetapiano. Dość dokładnie opisał działalność gabinetu dentystycznego w KL Auschwitz były więzień-lekarz Władysław Fejkiel ${ }^{5}$ oraz Roman Szuszkiewicz, który pracował $w$ ambulatorium dentystycznym. Na podstawie ich sprawozdań oraz wspomnień więźniów z KL Stutthof można wywnioskować, że dentystyka w Auschwitz działała znacznie lepiej niż w Stutthof, gabinet posiadał bowiem lepsze wyposażenie, a poza tym wykonywano nie tylko ekstrakcję, ale także wyjątkowo ciężkie przypadki leczenia szczęki, a sam gabinet był rozbudowany o protezownię, z której mogli korzystać jedynie członkowie SS.

$\mathrm{O}$ dentystyce $\mathrm{w}$ KL Stutthof nie powstał żaden odrębny artykuł. Bardzo ogólne informacje o funkcjonowaniu gabinetu dentystycznego znajdują się w artykule Mirosława Glińskiego pt. Organizacja i obsada personalna szpitala w obozie koncentracyjnym Stutthof ${ }^{6}$.

\footnotetext{
${ }^{3}$ A. Strzelecki, Wykorzystywanie zwłok ofiar obozu, „Zeszyty Oświęcimskie” 1995, nr 21, s. 92.

${ }^{4}$ Grupa więźniów zmuszana przez SS-manów do pracy przy usuwaniu ciał z komór gazowych i przy ich spalaniu.

${ }^{5}$ W. Fejkiel, Więźniarski szpital w KL Auschwitz, Oświęcim 1994, s. 41-43.

${ }^{6}$ M. Gliński, Organizacja i obsada personalna szpitala w obozie koncentracyjnym Stutthof, „Zeszyty Muzeum Stutthof” 1976, nr 1, s. 23-24.
} 
W zbiorze dokumentów w Archiwum Muzeum Stutthof w Sztutowie znajdują się dwa zbiory dotyczące dentystyki. Pierwszy - o sygnaturze I-VC-I - to dokumentacja dotycząca złota wydawanego SS-manom z lat 1942-1945, licząca 70 kart. W tym zespole można znaleźć:

a) pokwitowania dotyczące uzyskania lub wydania SS-manom takich materiałów, jak złoto czy ołowianka ${ }^{7}$,

b) pisma wysyłane do SS-Sanitätsamt z prośbą o dokonanie przetopienia złota dentystycznego z uzyskanych koron i mostków na złote sztabki,

c) kilka zachowanych kartotek stanu uzębienia członków załogi obozu, z których można wyczytać informacje dotyczące: zębów uszkodzonych, wypełnionych, brakujących, całkowicie zniszczonych, wyrzynania zębów mądrości, posiadanych klipsów protetycznych, zębów tymczasowych, koron, wkładów koronowo-korzeniowych i mostków, a także rodzaju zastosowanego leczenia i użytej w tym celu substancji,

d) orzeczenia o niepełnosprawności spowodowanej postrzałem w głowę, który skutkował porażeniem nerwu twarzowego.

Druga grupa to niewielki zbiór liczący 6 kart, o sygnaturze I-VC-2, z lat 1942-1943, przekazujących informacje dotyczące pozyskanej w danym miesiącu ilości złota dentystycznego (dla przykładu w styczniu $1943 \mathrm{r}$. uzyskano w drodze przetopienia 7,46 g złota, a w kwietniu 1943 r. 40,29 g ${ }^{8}$ ). Znajdują się w niej także pisma lekarza z prośbą o przydział stalowej kasety do przechowywania złotych zębów oraz wniosek o przesłanie złomu dentystycznego na adres Reichsführer SS und Chef der Deutschen Polizei SS-Wirtschafts-Verwaltungshauptamt A/II/3, Berlin Lichtferfelde, Unter den Linden 129/1369.

Dla porównania - w dokumentacji Archiwum Muzeum Auschwitz-Birkenau znajdują się protokoły oględzin meldunków o usunięciu sztucznych zębów, które podają informację, że w okresie od maja do grudnia 1942 r. wyrwano łącznie 16325 zębów wykonanych ze złota i stopów metali ${ }^{10}$.

7 W 1802 r. dentysta Luis Laforgue przedkładał ołów ponad inne materiały do wypełnień ubytków zębowych.

${ }^{8}$ Archiwum Muzeum Stutthof (AMS), Lagerarzt, Korespondencja dotyczaca detali dentystycznych zabieranych więźniom, I-VC-2, k. 3-6.

${ }_{9}$ Tamże, k. 2.

${ }^{10}$ APMA-B, Zespót Proces Hössa, t. 3, k. 84-86. 


\section{Ambulatorium dentystyczne w KL Stutthof}

Na wstępie warto nakreślić kilka podstawowych informacji o obozie koncentracyjnym Stutthof. Obóz Stutthof został założony 2 września 1939 r. w pobliżu wsi Sztutowo, znajdującej się 36 km od Gdańska. Już tego dnia przysłano do niego pierwszy transport, liczący 150 osób. 7 stycznia 1942 r. obóz zyskał status państwowego obozu koncentracyjnego i od tej pory podlegał centralnym władzom SS w Berlinie.

Pierwszym komendantem był SS-Hauptsturmführer Max Pauly, który zarządzał całym obozem od dnia utworzenia aż do 31 sierpnia 1942 r., kiedy to został przeniesiony do KL Neuengamme. Drugim komendantem został SS-Sturmbahnführer Paul Werner Hoppe, oficer SS-Totenkopfverbände, który we wcześniejszym okresie był członkiem załogi KL Dachau. Hoppe pełnił swoje funkcje do 4 kwietnia $1945 \mathrm{r}$.

Wyzwolenie miało miejsce 9 maja 1945 r. Szacuje się, że w ciągu 5 lat funkcjonowania KL Stutthof zarejestrowano ok. 110000 więźniów, z czego aż ok. 65000 poniosło w nim śmierć wskutek wykańczającej pracy, ekstremalnych warunków bytowych, niedostatecznej opieki lekarskiej, eksperymentów medycznych oraz morderczych ewakuacji ${ }^{11}$. Muzeum zostało utworzone 12 marca $1962 \mathrm{r}$.

Na podstawie dokumentacji znajdującej się w KL Stutthof można wywnioskować, że gabinet dentystyczny powstał dopiero w połowie listopada 1941 r. Funkcję dentysty pełnił dr Ernst Wedel, który podlegał lekarzowi obozowemu (Lagerarzt). Prócz niego w gabinecie pracowały dwie grupy: pierwszą byli SS-mani, a także drugi dentysta dr Hans Joachim Jantzen, który dołączył do zespołu w 1944 r.; drugą stanowili więźniowie, którzy pełnili funkcje pomocnicze. Głównym celem dentysty było pozyskanie złota dentystycznego. Zdobywanie złota należało do Goldarbeiterów, tj. więźniów-dentystów, którzy pod stałym nadzorem SS-manów dokładnie przeglądali uzębienie osób zagazowanych i szybko je wyrywali. Zęby były leczone bardzo sporadycznie, przeważnie natychmiast je usuwano. Oczywiście w przypadku załogi SS sytuacja wyglądała inaczej, ponieważ SS-mani mieli prawo do pełnej pomocy dentystycznej i leczenia zębów nawet w wyjątkowo beznadziejnych sytuacjach. Przywilejem leczenia uzębienia lub wykonywania zabiegów operacyjnych byli objęci (prócz załogi SS) więźniowie funkcyjni i honorowi.

${ }^{11}$ A. Coradello, Co się działo w Stutthofie, Warszawa 2011, s. 72. 


\section{Ambulatorium dentystyczne w KL Auschwitz}

KL Auschwitz został założony w pierwszej połowie 1940 r. Pierwszy transport więźniów liczył 728 osób z więzienia w Tarnowie i dotarł do obozu 14 czerwca 1940 r. ${ }^{12} \mathrm{~W}$ skład kompleksu obozu w Auschwitz wchodziły: obóz macierzysty, Auschwitz-Birkenau i Auschwitz-Monowitz. W KL Auschwitz zamordowano ok. 1,1 mln kobiet, mężczyzn i dzieci ${ }^{13}$. Tym samym stał się on największym obozem zagłady. Wyzwolenie obozu miało miejsce 27 stycznia $1945 \mathrm{r}$.

Pierwszymi założycielami ambulatorium dentystycznego w Auschwitz byli więźniowie: Janusz Kuczbara, Czesław Duzel i Antoni Jabłoński, a szefami SS-Sturmbannführer dr Karl Teuber i SS-Hauptsturmführer dr Willy Frank. Ambulatorium znajdowało się w bloku 21. Był to dość duży oddział, zajmujący dwie izby, z czego ta większa stanowiła gabinet zabiegowy, a ta druga była protezownią. Gabinet posiadał sprzęt, który odebrano śląskiemu lekarzowi-dentyście o żydowskim pochodzeniu. Tymi urządzeniami były: fotel, spluwaczka oraz unit, czyli wiertarka elektryczna wraz z reflektorem, lampą oświetleniową i urządzeniem do badania stanu miazgi ${ }^{14}$. Dodatkowo lekarze posiadali instrumenty do leczenia zarówno zachowawczego, jak i do zabiegów chirurgicznych. W gabinecie znajdował się także aparat Roentgena. Protezownia służyła przede wszystkim do czyszczenia zębów usuniętych z protez zębowych zabitych więźniów, a także wykonywano w niej dostawki ruchome i stałe, jednakże tylko dla SS. Materiały opatrunkowe były sterylizowane na oddziale chirurgicznym. Od połowy $1942 \mathrm{r}$. gabinet zaopatrzono $\mathrm{w}$ drugi fotel dentystyczny.

Zabiegi, które wykonywano, to przede wszystkim ekstrakcje i wypełnienia. Dopiero z czasem zaczęto przeprowadzać zabiegi chirurgiczne. Najczęstszymi przypadkami były: złamania i rany postrzałowe szczęki, ropowice, szczękościski oraz rak wodny (noma).

Na przełomie 1942/1943 r. ambulatorium otrzymało 10 łóżek dla ciężko chorych ${ }^{15}$. Na oddziale szczękowym panował od tej pory większy spokój, dzięki któremu więźniowie wracali do zdrowia. Otrzymywali bardziej wartościowy pokarm, który mogli w spokoju spożywać, i witaminy.

\footnotetext{
12 D. Czech, Kalendarz wydarzeń w KL Auschwitz, Oświęcim 1992, s. 14.

${ }_{13}^{13}$ F. Piper, Ilu ludzi zginęto w KL Auschwitz. Liczba ofiar w świetle źródet i badań, Oświęcim 1992.

${ }^{14}$ R. Szuszkiewicz, Dentystyka w obozie koncentracyjnym w Oświęcimiu, „Przegląd Lekarski - Oświęcim” 1964, nr 1, s. 77.

${ }^{15} \mathrm{~J}$. Krzywicki, Obrażenia szczękowe w obozie oświęcimskim, „Przegląd Lekarski Oświęcim” 1967, nr 1, s. 94.
} 


\section{Stan uzębienia więźniów}

Warunki obozowe miały ogromny wpływ na stan jamy ustnej więźniów. Brak możliwości utrzymywania należytej higieny oraz głodowe racje żywnościowe doprowadzały do tego, że więźniowie tracili zęby. Już po kilku miesiącach pobytu w obozie osadzeni zauważyli szybko postępujący proces próchnicowy, a po pewnym czasie zaczęły pojawiać się zmiany chorobowe $\mathrm{w}$ przyzębiu i na błonie śluzowej jamy ustnej. Występowało zaczerwienienie i blednięcie dziąseł, samoistne krwawienie, ich brzegi zaczęły się obniżać, a zęby ruszać ${ }^{16}$. Zdarzały się także zapalenia jamy ustnej i dziąseł. Początkowo występowało uczucie swędzenia, pieczenia, napięcia śluzówki i słodki posmak w ustach. Następnie pojawiały się naloty, a dookoła zaczerwienienie i obrzę $\mathrm{k}^{17}$.

W związku z tym, że w ambulatorium od razu wyrywano zęby, więźniowie próbowali leczyć uzębienie na „własną rękę”: pili zioła, przygotowywali wywary z łodyżek malin, płukali usta roztworem soli kuchennej, dodawali do jedzenia czosnek, cebulę i chrzan. By polepszyć ukrwienie dziąseł myli zęby bardzo ostrymi szczoteczkami ${ }^{18}$. Oczywiście zdobycie tych wszystkich środków wcale nie było takie proste, choćby z racji utrudnionego dostępu do nich. Problemy z uzębieniem były ostatecznym dowodem na wyniszczenie organizmu więźnia.

Duży wpływ na stan uzębienia miały też urazy szczękowo-twarzowe, które nieraz doprowadzały do złamania żuchwy lub zębów i prowadziły do ich wypadnięcia. Urazy powstawały podczas pracy, nieszczęśliwych wypadków, bombardowań i pobicia. W przypadku złamań szczęki przeprowadzano szynowanie, szynami drucianymi Hauptmeyera, szczęki złamanej i przeciwległej. Szyny doginano albo w ustach chorego, albo na modelach. Po osiągnięciu zwarcia wykonywano zdjęcie rentgenowskie. W cięższych przypadkach wykorzystywano aparaty w postaci szyn lanych $\mathrm{z}$ cierniami w przestrzeniach międzyzębowych i wąsami do wyciągów gumowych, które likwidowały zaklinowania odłamów ${ }^{19}$.

\section{Noma}

Rak wodny to choroba, która przez bakteryjne zapalenie śluzówek prowadzi do zniszczenia tkanek jamy ustnej i policzków. Występuje

${ }^{16}$ E. Franaszek, M. Chlebowska, T. Hoehne, Stan jamy ustnej więźniów w obozach koncentracyjnych, „Przegląd Lekarski - Oświęcim” 1977, nr 34, s. 26.

17 Tamże.

18 Tamże, s. 27.

19 J. Krzywicki, dz. cyt., s. 94. 
bardzo często jako powikłanie chorób zakaźnych i pojawia się u osób niedożywionych. Schorzenie było bardzo rozpowszechnione w XVIII i XIX w. w Europie, jednak już na początku XX w. nie było często spotykane.

W obozie koncentracyjnym Auschwitz na nomę chorowali głównie Cyganie, a zwłaszcza dzieci. Przypadkiem raka wodnego zajmował się przede wszystkim Josef Mengele. Rozwój choroby można podzielić na kilka etapów:

zapalenie jamy ustnej

pojawienie się ropnia

tworzenie się sinej plamki na wysokości zębów

wskutek rozpadu tkanek powstawała przetoczka

ubytek sie powiększat:

dochodziło do obnażenia zębów, dziąseł oraz kości szczękiं ${ }^{20}$, brzegi rany byty zaczerwienione, występowat silny obrzęk

Leczenie nomy ograniczało się do przepłukania jamy ustnej wodą utlenioną, która usuwała zapach rozkładających się tkanek, po czym zraszano brzegi rany prontosilem (środek antybakteryjny) i nakładano opatrunek. Na polecenie Josefa Mengele lekarze wybrali spośród wszystkich chorych grupę kilku osób, którą objęto leczeniem: dobrze odżywiano, przetrzymywano w normalnych warunkach i leczono farmakologicznie. W leczeniu zastosowano: sulfamidy, np. cibazol (środek o silnym działaniu bakteriostatycznym), witaminy - zwłaszcza witaminę $\mathrm{C}$ (cebion), mieszankę talku z prontosilem, nastrzykiwano rany takim preparatem, jak vaduril (używany do leczenia próchnicy i paradontozy ${ }^{21}$. Celem było stwierdzenie zależności rozwoju choroby od warunków bytowych oraz intensywności leczenia ${ }^{22}$. Jeśli zaobserwowano poprawę, sporządzano adnotację i zdjęcia, po czym ponownie skazywano więźnia na obozowe życie. Po tej zmianie stan chorych pogarszał się, co doprowadzało do nawrotu choroby. Po ponownej adnotacji i wykonaniu fotografii więźniów gazowano. Nomą zajął się także Horst Schumann, który podjął się leczenia rentgenologicznego.

${ }^{20}$ T. Szymański, Przypadki noma (rak wodny) w obozie cygańskim Oświęcim-Brzezinka, „Przegląd Lekarski - Oświęcim” 1962, nr 1, s. 69.

${ }^{21}$ R. Szuszkiewicz, dz. cyt., s. 78.

${ }^{22}$ APMA-B, Oświadczenia, t. 87, s. 92. 
Z relacji więźniów wynika, że planowano eksperymentować z nomą i przenieść chorobę $\mathrm{z}$ chorych na zdrowe dzieci ${ }^{23}$. Badania nad rakiem wodnym ustały wraz z likwidacją obozu cygańskiego.

\section{Analiza wybranego dokumentu dotyczącego leczenia zębów w KL Stutthof}

Źródłem, które zostanie przeanalizowane, jest skierowanie SS-Unterscharführera Ericha Mertensa do dentysty w celu przygotowania protezy wraz z zezwoleniem na użycie złota w celu jej wykonania $^{24}$. Pismo jest datowane na 18 lutego $1943 \mathrm{r}$.

\section{Informacje ogólne o dokumencie}

Dokument został wydrukowany przez Vordruckverlag W.F. Mayr Miesbach (Bayerischen Hochland) 13474 i nosi oznaczenie SSV S46. Czcionką dominującą jest fraktura. Dokument jako niewypełniony arkusz posiada kilka luk i kilka tabel, które uzupełniano głównie pismem maszynowym, w nielicznych miejscach znaleźć można także pismo odręczne. Na samym dole arkusza znajduje się podpis dentysty oraz pieczęć ze stopniem paramilitarnym. Pismo ma charakter oficjalny i składa się z trzech stron. Pierwsza strona to skierowanie na wykonanie protezy, czyli informacje odnośnie do stanu uzębienia danej osoby, oraz propozycja leczenia, druga strona to uzasadnienie o celowości wykonania mostku protetycznego oraz informacja, ile złotych koron wliczono w wykonanie protezy, należy zaznaczyć, że ta strona była wysyłana do Urzędu Sanitarnego z prośbą o zatwierdzenie i odpowiedź, czy wniosek został zaakceptowany całkowicie, czy częściowo. Strona trzecia to podsumowanie wypisane ręką osoby, dla której wykonano protezę, z informacjami odnośnie do finalnej ilości zużytego materiału oraz tabelami, w których znajdują się dane dotyczące wprowadzenia zmian, kontroli i ewentualne uwagi.

\section{Analiza skierowania}

Na wstępie skierowania znajduje się adnotacja wstępna dotycząca przygotowania propozycji i planu leczenia wraz z podaniem kosztów wynikających z umowy między Bankiem Rzeszy a Stowarzyszeniem

${ }^{23}$ Por. K. Okoniewska, Zbrodniczy medycy. Lekarze z Auschwitz, Łódź 2017, s. $121-125$.

${ }^{24}$ AMS, Dokumentacja wydawanego SS-manom złota, sygn. I-VC-I, s. 19. 
lekarzy KZV ${ }^{25}$. Następnie widnieją informacje odnośnie do całego uzębienia SS-mana, który ma być poddany leczeniu. Istotnym elementem karty jest tabela ukazująca stan całego uzębienia. Jest ona podzielona na kilka części: pierwsza to cyfry od 1 do 8 , odpowiadające konkretnym zębom, druga to podział na zęby górne i dolne, trzecia to rozróżnienie na prawą i lewą stronę szczęki. Umieszczone $\mathrm{w}$ tabeli dane dotyczą stanu poszczególnych zębów i podawane są one w formie znaku lub skrótu, np.:

/ - beschädigt, ząb uszkodzony

- - gefüllt, ząb wypełniony

$\mathrm{f}-$ fehlt, ząb brakujący

+ - ganz zerstört oder Wurzel, ząb całkowicie zniszczony lub korzeń

$\mathrm{w}$ - noch zu erwartenden Weisheitszahn, niewyrżnięty ząb mądrości

$\mathrm{Pl}$ - Platte, płytka

$\mathrm{Kl}$ - Klammer, klips protetyczny

$\mathrm{k}$ - künstlicher Zahn, ząb sztuczny

$\mathrm{kr}$ - Krone, korona

St - Stiftzahn, wkład koronowo-korzeniowy

$\mathrm{Br}$ - Brücke, mostek

Na podstawie tych informacji można łatwo rozszyfrować stan uzębienia badanego SS-mana.

Po prawej stronie szczęki zarówno zęby górne, jak i dolne były w gorszym stanie niż po stronie lewej. Erich Mertens nie miał kilku zębów trzonowych. W przypadku zębów górnych po prawej stronie zanotowano: dwa ubytki - brak zęba piątego i szóstego, a na dole brak zęba siódmego. Po stronie lewej brakowało zęba siódmego i ósmego, na dole odnotowano brak wszystkich trzech trzonowców. Mertens posiadał także jedną koronę na górnej, prawej jedynce ${ }^{26}$.

Prócz sporych braków występowały też liczne wypełnienia, w zdecydowanej większości po prawej stronie szczęki, w jej górnej części znajdowało się ono w każdym zębie. Na dole po prawej wypełnień było mniej, jedynie w szóstce i ósemce. Lewa strona szczęki miała mniejszą liczbę plomb. Na górze znajdowały się one w piątce i szóstce, a na dole żaden ząb nie był w taki sposób leczony.

Druga tabela przedstawia proponowany sposób leczenia. Erichowi Mertensowi zaproponowano uzupełnienie prawej, górnej części szczęki, w której znajdowały się dwa ubytki, tuż obok siebie. Jako najlepsze rozwiązanie lekarz przyjął zastosowanie czteropunktowego

${ }^{25}$ Kassen-Zahnärztlichen-Vereinigung.

${ }^{26} \mathrm{Na}$ drugiej stronie dokumentu widnieje informacja, że jest to korona złota. 
mostu $^{27}$ na dwóch zębach: wykonanie korony ${ }^{28}$ na czwórce i siódemce oraz przymocowanie mostu protetycznego do naturalnych zębów.

W kolejnym etapie dokumentu podawano ilość materiału, który miał zostać zużyty do wykonania konkretnego rodzaju protezy, i określano przypuszczalne koszty zgodnie z przyjętym wzorem:

- określano, ile zębów łącznie brakuje w górnej/dolnej szczęce,

- podawano rodzaj materiału, z jakiego wykonano płytkę stomatologiczną,

- liczba wstawionych sztucznych zębów z zaznaczeniem, czy są nowe, czy wymieniono stare,

- liczba założonych klipsów protetycznych, suma wykonanych płytek ochronnych na zęby,

- informowano, czy miało miejsce odtworzenie zęba w przypadku złamania,

- wymieniano liczbę zastosowanych wkładów koronowo-korzeniowych i koron,

- pisano, z jakiego materiału wykonano mostek i z ilu części się składał,

- na końcu podawano, jakie koszty materiałowe poniesiono w przypadku leczenia górnej i dolnej szczęki oraz jaka jest łączna kwota.

W przypadku SS-Unterscharführera Ericha Mertensa wykonano adnotację, że mostek protetyczny, składający się z trzech części, wykonany będzie ze złota i palapontu ${ }^{29}$. W koszty materiałowe wliczono 4,5 g złota oraz 0,5 g ołowianki. Dokument został podpisany przez dr. Karla Abrahama ${ }^{30}$.

${ }^{27}$ Most jest uzupełnieniem, którego celem jest odbudowanie brakujących zębów. Mocowany jest na zębach oskrzydlających lukę. Nie może być stosowany w przypad$\mathrm{ku}$ stwierdzenia ruchomości zębów filarowych. Istnieje podział na mosty klasyczne (długość luki może wynosić od 1 do 4 zębów) i adhezyjne (tylko 1 ząb) (S. Majewski, Wspótczesna protetyka stomatologiczna. Podstawy teoretyczne i praktyka kliniczna, Wrocław 2014, s. 183). Most protetyczny stosuje się m.in.: aby uniknąć przemieszczania zębów w przypadku luk, chorób dziąseł i próchnicy spowodowanej przez akumulację jedzenia w lukach, aby odzyskać prawidłowy zgryz.

${ }^{28}$ Korona jest uzupełnieniem protetycznym, które pozwala na odbudowę zniszczonych koron zębów. Korony pokrywają ząb naturalny do poziomu jego szyjki i są wykonywane na podstawie modelu oszlifowanego zęba własnego. Brzeg korony przebiega naddziąsłowo, dodziąsłowo lub w przypadku ubytków rozleglejszych także poddziąsłowo (tamże, s. 182). Nakłada się ją m.in.: w celu zabezpieczenia stałego zęba przed złamaniem, by umocować most protetyczny lub by pokryć ząb po leczeniu kanałowym.

${ }^{29}$ Palapont to rodzaj białej masy akrylowej. Zastosowanie: sztuczne zęby, protezy, korony, mosty, płytki i żywice syntetyczne stosowane w połączeniu z wypełniaczami i do zębów oraz materiały do formowania do celów dentystycznych.

${ }_{30}$ Pracował w gabinecie w okresie od stycznia 1943 r. do końca marca 1944 r. 
Pośród skierowań na wykonanie protezy znajduje się także propozycja leczenia dla samego komendanta obozu Paula Wernera Hoppego, któremu wykonano aż sześć koron i pięć mostków, co pochłonęło $22 \mathrm{~g}$ złota. Podobnych pism i sposobów leczenia można jeszcze znaleźć kilka.

Reasumując, karty dentystyczne zachowane w KL Stutthof potwierdzają relacje więźniów, którzy wspominając funkcjonowanie gabinetu dentystycznego, podkreślali, że dla SS-manów pełnił on zupełnie przeciwną funkcję niż dla nich. W zbiorze nie ma ani jednej karty dotyczącej jakiegokolwiek sposobu leczenia zębów któregokolwiek więźnia, jest zatem wielce prawdopodobne, że w ich przypadku nie robiono żadnej adnotacji.

Uwage przykuwa fakt, że zachowana dokumentacja jest bardzo dokładna i wiernie odzwierciedla realia obozowe, zarówno dotyczące leczenia załogi SS, jak i ponownego wykorzystania ciał zmarłych więźniów.

Same źródła dotyczące tematu funkcjonowania dentystyki są bardzo liczne, stanowią je nie tylko oryginalne dokumenty, takie jak: karty ewidencyjne uzębienia więźniów/załogi SS, korespondencja $\mathrm{z}$ wydziałem sanitarnym czy zaświadczenia dotyczące pobierania złota przez SS-manów, ale przede wszystkim relacje więźniów. Moim zdaniem analiza dokumentacji pomoże w pełni zobrazować ogólną działalność dentystów i ich gabinetów w obozach koncentracyjnych, takich jak Auschwitz czy Stutthof. Badania nad dentystyką w KL Stutthof nadal trwają.

\section{Summary \\ Dental practice in the Auschwitz and Stutthof concentra- tion camp}

The aim of the article is to present the functioning of the dental offices in the concentration camps KL Stutthof in Sztutowo and KL Auschwitz in Oświęcim. The state of knowledge about dentistry at Stutthof camp is inadequate, because it has not been properly elaborated. In the concentration camps, both the doctor and the dentist, were almost not associated with medical help. A dental office was established in KL Stutthof in November 1941 when Ernst Wedel arrived, in Auschwitz much earlier and the first founders were polish prisoners, who always tried to help the most sick people, but the chiefs were SS-Sturmbannführer dr Karl Teuber and SS-Hauptsturmführer dr Willy Frank. The main tasks of the dentist was to take care of the SS staff and prisoners, but only the camp's crew was surrounded with full medical care. 
The article presents a short analysis of sources, confirming that the SS-personnel were treated even when the case of tooth diseases was very serious, but when it comes to the prisoners, they could have tooth removal or sometimes jaw surgery. The most important task was to keep the records of prisoners with artificial teeth made of gold and other precious metals. After prisoners death, the doctor removed his teeth out and then melted down so that it could finally be sent to Goldverwaltung. 